\author{
*УДК 336.145.1 \\ Діденко Л.В., к.е.н., доцент \\ Пужакова А.С. \\ Університет державної фіскальної служби України
}

\title{
АНАЛІЗ СУЧАСНОГО СТАНУ СТРАХОВОГО РИНКУ УКРАЇНИ
}

У статті розглянуто діяльність на страховому ринку, його значення на ринку фінансових послуг. Проаналізовано сучасній стан страхового ринку України за останні п'ять років.

Ключові слова: страховий ринок, ринок фінансових послуг, страхувальник, страховик, страхові посередники, страхова діяльність.

\section{Didenko L., Puzhakova A. \\ THE ANALYSIS OF THE CURRENT SITUATION OF THE INSURANCE MARKET OF UKRAINE}

The insurance market is an integral part of the financial market, as it responds sensitively to all the problems in it. Positive changes in the economy, increasing the welfare of the population contribute to the activity of insurance companies, and the stable development of the latter creates conditions for improving the state of the economy by investing their accumulated cash in various areas and industries.

The modern insurance market has reached a certain level of development, but has not become quite stable and in its characteristics does not meet the current challenges of the Ukrainian economy and the requirements of world insurance markets in the process of globalization.

Insurance market - a special area of monetary relations, where the object of sale is a specific service - insurance protection, formed the supply and demand for it.

Over the past five years, we can observe the tendency to reduce insurance companies. This is due to the elimination of companies other than life insurance. The main reasons for reducing the number of insurance companies are their lack of capitalization, low asset quality, devaluation of the national currency, an unstable internal political and economic situation in the country.

Over the past years, the development of the insurance market has slowed down, because the necessary reforms, both legislation and the market as a whole, have not been carried out.

The following factors hinder the development of the Ukrainian insurance market: the absence of a clear policy in the field of state regulation and effective supervision of the activities of market entities, which facilitates shadowing of operations, increase of

* Діденко Л.В., Пужакова А.С. 
financial circuits, outflow of capital abroad; decrease of demand for insurance services in the conditions of lowering the solvency of the population, low level of trust in financial institutions; lack of mechanisms for tax incentives for investment activity of insurance companies, low level of long-term life insurance market development; underdevelopment of the rating system of insurers, market opacity, lack of effective mechanisms for protecting the rights of policyholders; lack of infrastructure development, absence of an approved state concept of insurance market development, state insurance intermediary training programs (brokers, underwriters, emergency commissioners, etc.); weak stock market; as a result - the lack of reliable financial instruments for investing, low quality assets to cover insurance reserves.

The formation of the insurance market in Ukraine, its further successful development will depend on expanding the list of insurance services, increasing their competitiveness, expanding the infrastructure, increasing the requirements for the establishment of the activity of insurance organizations, further integration of Ukraine into international structures, and establishing an optimal structure of the relationship between compulsory and voluntary insurance.

Key words: insurance market, financial market, insurer, insurance intermediaries, insurance activity.

\section{Диденко Л.В., Пужакова А.С. \\ АНАЛИЗ СОВРЕМЕННОГО СОСТОЯНИЯ СТРАХОВОГО РЫНКА УКРАИНЫ}

В статье рассмотрено содержание понятия страховой рынок, его значение на рынке финансовых услуг. Проанализировано состояние страхового рынка Украины за последние пять лет.

Ключевые слова: страховой рынок, рынок финансовых услуг, страхователь, страховщик, страховые посередники, страховая деятельность.

Постановка проблеми у загальному вигляді та її зв'язок 3 важливими науковими та практичними завданнями. Страховий ринок є невід'ємною складовою фінансового ринку, адже він чутливо реагує на всі проблеми, що відбуваються в ньому. Позитивні зміни в економіці, підвищення добробуту населення сприяють активності страхових компаній, а стабільний розвиток останніх створює умови для покращення стану економіки шляхом інвестування накопичених ними грошових коштів у різні їі сфери та галузі. На даний момент страхування чи не єдина галузь в Україні, яка має більш менш стабільний розвиток та приріст обсягів наданих послуг. 
Аналіз останніх досліджень, у яких започатковано вирішення проблеми. Дослідженню питань, пов'язаних 3 розвитком страхового ринку, присвячені наукові праці таких науковців: Л. І. Васечко, В. В. Волкової, К. М. Дзюбак, Ю. М. Дьячкової, О. А. Клепікової, Я. В. Моторної, А. С. Шолойко.

Цілі статті. Метою написання даної статті є дослідження теперішнього стану страхового ринку України.

Виклад основного матеріалу дослідження 3 повним обгрунтуванням отриманих наукових результатів. Сучасний страховий ринок набув певного рівня розвитку, але не став достатньо стабільним і за своїми характеристиками не відповідає сучасним завданням розвитку економіки України та вимогам світових страхових ринків у процесі глобалізації.

Відсутність усталеного визначення функцій страхового ринку в теорії та практиці страхування, а також у нормативнозаконодавчій базі потребує проведення серйозних досліджень у цьому напрямі.

Зміни, що відбуваються в економіці, підвищують значення розвитку страхового ринку, з'являється необхідність створення дієвої системи страхового захисту з метою забезпечення стабільності розвитку та ефективності економічних відносин, підвищення рівня життя населення, соціальної стабілізації.

Страховий ринок - особлива сфера грошових відносин, де об'єктом купівлі-продажу виступає специфічна послуга - страховий захист, формується пропозиція і попит на неї [3].

Учасниками страхового ринку є: страхувальники, застраховані, вигодонабувачі, страховики, перестраховики, товариства взаємного страхування, страхові та перестрахові брокери, страхові агенти, актуарії; професійні об'єднання страховиків, страхових посередників та інших учасників страхового ринку [1].

У табл. 1 наведено данні щодо кількості страхових компаній за останні 5 років.

За останні п’ять років, можемо спостерігати тенденцію до зменшення страхових компаній. Це пов'язано з ліквідацією компаній відмінних від страхування життя. 
Економічні науки". - Серія "Облік і фінанси". - Випуск 15 (57). - 2018.

Таблиця 1

Кількість страхових копаній за 2013-2017 рр.

\begin{tabular}{|c|c|c|c|c|c|}
\hline Показники & 2013 & 2014 & 2015 & 2016 & 2017 \\
\hline К-ть страхових компаній: & 407 & 382 & 361 & 310 & 294 \\
\hline CK «life» & 62 & 57 & 49 & 39 & 33 \\
\hline CK «non-life» & 345 & 325 & 312 & 271 & 271 \\
\hline
\end{tabular}

Джерело: складено автором на основі [4]

Основними причинами зменшення кількості страхових компаній $є$ їх недостатня капіталізація, низька якість активів, девальвація національної валюти, нестабільна внутрішня політична та економічна ситуація в країні.

Проаналізуємо як змінилась кількість договорів страхування за останні 5 років.

Таблиця 2

Кількість договорів страхування за 2013-2017 рр.

\begin{tabular}{|c|c|c|c|c|c|}
\hline Показники & 2013 & 2014 & 2015 & 2016 & 2017 \\
\hline $\begin{array}{c}\text { Кількість } \\
\text { договорів: }\end{array}$ & 185280,5 & 134713,2 & 202429,3 & 179471,2 & 185482,9 \\
\hline $\begin{array}{c}\text {-зі страхуваль- } \\
\text { никами - фізи- } \\
\text { чними особами }\end{array}$ & 80345,0 & 32699,4 & 106321,2 & 42534,6 & 66915,2 \\
\hline $\begin{array}{c}-3 \\
\text { обов'язкового } \\
\text { особистого } \\
\text { страхування } \\
\text { від нещасних } \\
\text { випадків на } \\
\text { транспорті }\end{array}$ & 97952,0 & 98737,5 & 93322,5 & 118198,4 & 114824,7 \\
\hline
\end{tabular}

Джерело: складено автором на основі [4]

3 даних табл. 2 можемо зробити висновок, що у 2014 році відбулось зменшення кількості договорів страхування на 50569,3 договорів, але кількість договорів із обов'язкового особистого страхування від нещасних випадків на транспорті має тенденцію до збільшення. 
У 2015 році відбулось зростання загально кількості договорів на 67716,1 договір, а кількість договорів із обов'язкового особистого страхування від нещасних випадків на транспорті зменшились.

У 2016 році відбулося зменшення загальної кількості договорів страхування, проте кількість договорів із обов'язкового особистого страхування від нещасних випадків на транспорті збільшилась на 24875,9 договорів.

У 2017 році кількість договорів страхування збільшилась, проте не досягла відмітки 2015 року, а кількість договорів із обов'язкового особистого страхування від нещасних випадків на транспорті зменшилась на 3373,7 договорів.

Проаналізуємо основні показники страхової діяльності за 2013-2017 pp.

Таблиця 3

Основні показники страхової діяльності за 2013-2017 рр., млн. грн

\begin{tabular}{|c|c|c|c|c|c|}
\hline Показники & 2013 & 2014 & 2015 & 2016 & 2017 \\
\hline Валові страхові премії & 28661,9 & 26767,3 & 29736,0 & 35170,3 & 43431,8 \\
\hline Валові страхові виплати & 4651,8 & 5065,4 & 8100,5 & 8839,5 & 10536,8 \\
\hline Чисті страхові премії & 21551,4 & 18592,8 & 22354,9 & 26463,8 & 28494,4 \\
\hline Чисті страхові виплати & 4566,6 & 4893,0 & 7602,8 & 8561,0 & 10256,8 \\
\hline $\begin{array}{c}\text { Обсяг сформованих } \\
\text { страхових резервів }\end{array}$ & 14435,7 & 15828,0 & 18376,3 & 20936,7 & 22864,4 \\
\hline $\begin{array}{c}\text { - резерви зі страхування } \\
\text { життя }\end{array}$ & 3845,8 & 5306,0 & 6889,3 & 7828,2 & 8389,6 \\
\hline - технічні резерви & 10589,9 & 1052 & 11487 & 13108,5 & 14474,8 \\
\hline
\end{tabular}

Джерело: складено автором на основі [4]

Отже, за останні п'ять років валові страхові премії збільшились на 14769,9 млн. грн., а валові страхові виплати - на 5885 млн. грн. Обсяг сформованих страхових резервів збільшився на 4543,8. Спостерігається збільшення, проте враховуючи рівень інфляції та девальвації національної валюти, можна зробити висновок, що позитивних зрушень майже немає, хоча страховий ринок є тою галуззю в Україні, яка має хоч невелике зростання.

Протягом останніх років розвиток страхового ринку сповільнився, адже не були проведені необхідні реформи, як законодавства, так і ринку в цілому.

Можна виділити наступні чинники, які гальмують розвиток страхового ринку України [2]: 
- відсутність чіткої політики в області державного регулювання і ефективного нагляду за діяльністю суб'єктів ринку, що сприяє тінізації операцій, збільшенню фінансових схем, відпливу капіталу за рубіж;

- зниження попиту на страхові послуги в умовах зниження платоспроможності населення, низького рівня довіри до фінансових установ;

- відсутність механізмів податкового стимулювання інвестиційної активності страхових компаній, низький рівень розвитку ринку довгострокового страхування життя;

- нерозвиненість системи рейтингової оцінки страховиків, непрозорість ринку, відсутність дієвих механізмів захисту прав страхувальників;

- нерозвиненість інфраструктури, відсутність затвердженої державної концепції розвитку страхового ринку, державних програм підготовки страхових посередників (брокерів, андеррайтерів, аварійних комісарів і ін.);

- слабкий фондовий ринок; як наслідок - відсутність надійних фінансових інструментів для інвестування, низька якість активів в покриття страхових резервів.

Висновки. Страховий ринок є надзвичайно складною багаторівневою системою, яку утворює низка взаємопов'язаних і взаємообумовлених підсистем: страхових продуктів, тарифів, організації продажу і формування попиту, інфраструктури тощо.

Аналіз сучасного стану, тенденцій і проблем розвитку вітчизняного страхового ринку свідчить про певні здобутки та численні недоліки, притаманні функціонуванню як окремих страхових компаній, так і всієї системи страхування.

Становлення страхового ринку в Україні, подальший його успішний розвиток залежатиме від розширення переліку страхових послуг, підвищення їхньої конкурентоспроможності, розширення інфраструктури, підвищення вимог до порядку створення діяльності страхових організацій, подальшої інтеграції України у міжнародні структури, а також створення оптимальної структури співвідношення між обов'язковим і добровільним страхуванням. 
1. Волкова В.В. Методичні аспекти державного регулювання страхового ринку України / В. В. Волкова // Економіка і організація управління. - вип. № 4 (24). - 2016. - c. 138.

2. Дьячкова Ю. М. Страховий ринок в умовах нестабільної економіки / Ю. М. Дьячкова // Вісник Донбаської державної машинобудівної академії. - вип. №2 (33). - 2014. с. 173.

3. Діденко Л.В. Інвестиційна діяльність страхових компаній в сучасних умовах /Л.В. Діденко // Збірник наукових праць Національного університету ДПС України:фахове видання (економіка). - [Електронний ресурс] / Національний університет державної податкової служби України; гол. Ред..: Л.Л. Тарангул. 2014. - № 1. - Режим доступу http://www.nbuv.gov.ua/e-journals/Znpnudps/in dex.html . - Заголовок з екрана. - C. 68-80.

4. Офіційний сайт Національної комісії, що здійснює державне регулювання у сфері ринків фінансових послуг - [Електронний ресурс]. - Режим доступу: https://www.nfp.gov.ua.

\section{*УДК 336.43}

Діденко Л.В., к.е.н., доцент

Чорна I.O.

Університет державної фіскальної служби України

\section{ОВДП ЯК НАДІЙНИЙ ФІНАНСОВИЙ ІНСТРУМЕНТ IНВЕСТУВАННЯ В ЕКОНОМІКУ УКРАЇНИ}

У статті розглянуто розвиток ринку ОВДП. Обгрунтовано інвестиційну привабливість державних облігацій та шляхи удосконалення їх продажу серед резидентів та нерезидентів України на фоні соціально-економічних умов.

Ключові слова: державні облігації, державні зобов'язання, фінансовий ринок, інвестиції, ОВДП.

\section{Didenko L., Chorna I. \\ THE INTERNAL GOVERNMENT BONDS AS A RELIABLE FINANCIAL INSTRUMENT FOR INVESTMENT IN UKRAINIAN ECONOMY}

This article is about the benefits of the internal government bonds. Today, the economic situation of Ukraine is really complicated and needs a strong political plan of development. The author in the paper analyzes the dynamic and the structure of owners

* Діденко Л.В., Чорна І.О. 